\title{
Pemetaan Bibliometrik Perkembangan Publikasi Ilmiah Sains Terbuka Periode Tahun 2000-2019
}

\author{
$\operatorname{Tupan}^{1 *}$ \\ ${ }^{1}$ Pusat Data dan Dokumentasi Ilmiah LIPI \\ *Korespondensi: tupan712190@gmail.com
}

\begin{abstract}
A bibliometric mapping-based research on the development of the open science research had been done based on Scopus data within the period of 2000 to 2019 has been carried out which aims to to measure the productivity of open science's scientific publications based on year, core journals publishing open science research, the most productive open science research's authors, the number of scientific publications on the open science research based on the affiliation/institution, the country, the type of documents, and the research funding. It also aims to map the development of open science research through a keywords' clustering using a VOSviewer software. The research was conducted through an information retrieval on the Scopus database by using keywords "open science”. The Scopus data was explored based on the research aims. Later, the VOSviewer software was used to visualize the development of the open science research. The result of the research showed that the peak of the scientific publications' growth on the open science research was happened in 2018, that was about 230 publications. The core journals published the most open science publications were Royal Society Open Science with 26 publications, followed by Journal of Physics Conference Series with 23 publications, and Nature with 18 publications. The most productive author writing on the open science research was Quick $R$ from Indiana University. Most publications on the open science research was funded by the National Science Foundation, that is about 54 publications. The mapping result using the VOSviewer software showed that the development of the open science publications was clustered into 6 clusters.
\end{abstract}

Keywords: mapping science; bibliometric; open science

\begin{abstract}
Abstrak
Kajian ini melakukan pemetaan bibliometrik tentang perkembangan penelitian sains terbuka berbasis data scopus periode tahun 2000-2019 yang bertujuan untuk mengetahui produktivitas publikasi Ilmiah tentang sains terbuka berdasarkan tahun; jurnal Inti yang mempublikasikan tentang penelitian sains terbuka; jumlah penulis terproduktif; jumlah publikasi ilmiah tentang sains terbuka berdasarkan afiliasi/ lembaga, negara, tipe dokumen; dan sponsor penandanaan; serta untuk memetakan perkembangan penelitian sains terbuka melalui clustering kata kunci menggunakan software VOSviewer. Kajian ini dilakukan melalui penelusuran informasi pada database Scopus menggunakan kata kunci "open science". Selanjutnya, data dari database scopus dieksplorasi sesuai tujuan penelitian. Lebih lanjut, software VOSviewer digunakan untuk memvisualisasikan perkembangan penelitian tentang sains terbuka. Hasil penelitian menunjukkan bahwa pertumbuhan publikasi ilmiah tentang sains terbuka yang terindeks di scopus puncaknya terjadi pada tahun 2018 yaitu sebanyak 230 publikasi. Jurnal inti yang mempublikasikan publikasi ilmiah sains terbuka terbanyak adalah Royal Society Open Science sebanyak 26 publikasi, kemuadian dsusul Journal of Physics Conference Series 23 publikasi, Nature 18 publikasi. Penulis yang paling produktif menulis tentang open science adalah Quick R dari Indiana University. Publikasi ilmiah sains terbuka yang terbanyak mendapatkan sponsor penandanaan dari National Science Foundation sebesar 54 publikasi. Hasil pemetaan menggunakan sofware VOSviewer menunjukkan bahwa perkembangan publikasi sains terbuka terbagi menjadi 6 kluster.
\end{abstract}

Kata Kunci: pemetaan ilmu pengetahuan; bibliometrik; sains terbuka

\section{PENDAHULUAN}

Sains terbuka mempunyai misi membawa perubahan sosial budaya dan teknologi berdasarkan keterbukaan dan konektivitas, yang mencakup bagaimana penelitian dirancang, dilakukan, disimpan, dan dinilai. Sains terbuka mencakup data terbuka, platform akses terbuka, metode peer review terbuka, atau kegiatan keterlibatan publik adalah tren yang tidak dapat diubah, yang berdampak pada semua aktor ilmiah dan memiliki potensi untuk mempercepat siklus penelitian (Vicente-Saez and Martinez-Fuentes (2018). Secara konseptual sains terbuka adalah ilmu pengetahuan yang transparan dan dapat diakses, yang tersebar dan berkembang melalui 
jaringan kerjasama. Dalam kegiatannya, sains terbuka adalah sebuah gerakan yang bertujuan agar penelitian ilmiah dalam bentuk data dan publikasi dapat diakses oleh masyarakat luas dari berbagai kalangan yang membutuhkan. Sains terbuka karakter kata kuncinya adalah keterbukaan, berbagi segera, kolaborasi, diseminasi luas dan perbaikan berkelanjutan ( Irawan, D.E. dkk, 2017).

Dalam pendistribusian akses pengetahuan, pengetahuan terbuka mempunyai peraranan dalam membuat pengetahuan ilmiah (termasuk penerbitan, kode, metode, dan data) mudah diakses dan tersedia gratis untuk setiap orang yang melalui akses teknologi modern menggunakan koneksi internet. Sains terbuka menandakan prinsip-prinsip keterbukaan dan transparansi yang memiliki daya tarik luas dan intuitif. Perdebatan yang sedang berlangsung seputar ruang lingkup 'keterbukaan' dan aspek 'sains' yang harus diaplikasikan. Prinsip dan pedoman untuk akses ke data penelitian dari pendanaan publik (OECD, 2007). Penjabarkan prinsip-prinsip lebih lanjut untuk memandu para peneliti dan dalam beberapa kasus memerlukan tawaran pendanaan untuk disertai dengan rencana manajemen data. Pedoman OECD mendefinisikan keterbukaan sebagai akses dengan syarat yang setara untuk komunitas penelitian internasional dengan biaya serendah mungkin, lebih disukai tidak lebih dari biaya marjinal penyebaran. Akses terbuka ke data penelitian dari pendanaan publik harus mudah, tepat waktu, ramah pengguna dan lebih disukai berbasis internet.

Sains terbuka adalah gerakan untuk membuat penelitian ilmiah, data, dan penyebaran dapat diakses oleh semua tingkatan masyarakat yang membutuhkan (Foster, 2018). Hal senada juga dikatakan oleh Vicente-Saez \& Martinez-Fuentes (2018) bahwa secara konseptual sains terbuka adalah ilmu pengetahuan yang transparan serta dapat diakses, tersebar dan berkembang melalui jaringan kerjasama. Dalam pengertian sebagai sebuah aksi, sains terbuka adalah gerakan yang bertujuan agar penelitian ilmiah dalam bentuk data dan publikasi dapat diakses oleh masyarakat luas dari berbagai kalangan yang membutuhkan.

Miedema, Maye, Holmberg, Leonelli ( 2018) sains terbuka didasarkan pada gagasan bahwa pengetahuan ilmiah dari semua jenis harus dapat diakses secara terbuka. Sains terbuka menuntut transparansi maksimum dan kemampuan berbagi dalam produksi dan transfer pengetahuan serta partisipasi (semua) pemangku kepentingan yang relevan dalam proses ilmiah. Gerakan sains terbuka berusaha untuk meningkatkan reproduktifitas dan akuntabilitas, usabilitas dan inovasi, kolaborasi dan partisipasi masyarakat yang menghormati keanekaragaman, keadilan dan tanggung jawab sosial. Dimensi-dimensi ini membutuhkan perubahan yang luas dan sistemik dalam praktik komunikasi ilmiah saat ini, terutama dalam konfigurasi ulang penerbitan dan evaluasi, dengan pertimbangan yang cermat terhadap budaya penelitian dan kebutuhan masyarakat. Perubahan paradigmati yang mendasar seperti itu menuntut pengakuan akan kualitas ilmiah lebih dari apa yang dapat ditemukan dalam publikasi belaka dalam jurnal dan buku. Fokus bergeser ke arah penelitian dalam pembuatan, bentuk-bentuk output lain, seperti data atau alur kerja dan metode, serta berbagai jenis keterlibatan dan inovasi sosial. Oleh karena itu, sains terbuka mencakup akses ke publikasi, metode dan data penelitian, bentuk evaluasi terbuka termasuk peer review, metrik dan prosedur perekrutan, sumber daya pendidikan terbuka, dan sains warga negara (Miedema, Mayer, Holmberg, Leonelli, 2018).

Penelitian terdahulu tentang bibliometrik yang berhubungan dengan sains terbuka pernah dilakukan oleh Kumar (2016) melakukan analisis bibliometrik jurnal akses terbuka dengan subjek 'matematika' yang diindeks dalam directory of open access journals (DOAJ). Analisis bibliometrik yang digunakan adalah jurnal dengan judul subjek matematika, negara asal publikasi, bahasa yang digunakan dalam jurnal, penerbit jurnal, korelasi jurnal matematika dengan bidang subjek lainnya, kebijakan peer review, kebijakan pengarsipan, keamanan dan fitur standar yang dipakai oleh jurnal. Sebanyak 556 jurnal dalam subjek matematika dianalisis dalam penelitian ini. Hasil kajian menunjukkan bahwa jurnal terbanyak dalam subjek matematika diindeks adalah subjek sains, 
jurnal terbanyak terjadi pada tahun 2013, jumlah jurnal terbanyak diterbitkan dalam format 'cetak, Hindawi Publishing Corporation merupkan penerbit terbanyak dalam subjek matematika, India adalah kontributor utama untuk jurnal matematika; Portico adalah agen pengarsipan utama; dan jurnal terbanyak diindeks dalam DOAJ tanpa biaya pemrosesan untuk publikasi artikel. Anil, $d k k$ (2010) melakukan analisis terhadap 4338 publikasi tentang tsunami yang diindeks dan disitir dalam database Scopus selama 1997-2008 menunjukkan bahwa jumlah publikasi terbanyak terbanyak terjadi pada tahun 2005 yaitu sebanyak 1053 publikasi dan telah disitir sebanyak 4022 kali.

Setyowati dan Heriyanto (2019) melakukan penelitian yang bertujuan untuk memetakan domain pengetahuan dalam manajemen data penelitian, khususnya dalam hal pengaturan pendidikan tinggi. Dengan menggunakan VOSviewer, penelitian ini mengidentifikasi penulis, publikasi, dan topik yang paling berpengaruh di lapangan. Hasilnya menunjukkan bahwa Tenopir dan publikasinya adalah yang paling menonjol di lapangan dan topik yang sedang hangat adalah penelitian RDM-HE yang berkaitan dengan perpustakaan perguruan.

Kirtania (2018) melakukan kajian untuk mengetahui pertumbuhan dan perkembangan literatur ilmu sosial di lingkungan akses terbuka yang diterbitkan dari India. Publikasi yang digunakan dalam kajian ini adalah mulai dari tahun 2008 sampai dengan 2017. Publikasi dianalisis berdasarkan pertumbuhan literatur, pola kepengarangan, indeks aktivitas, penulis dan lembaga yang produktif, jenis publikasi, dan jumlah kutipan untuk memberikan gambaran yang jelas tentang penelitian ilmu sosial India. Hasil penelitian menunjukkan dominasi kepengarangan bersama dan $60 \%$ dari total artikel telah dikutip. Produktivitas penelitian ilmu sosial secara terbuka mengakses konteks dan akan membantu ilmuwan sosial dan profesional perpustakaan secara keseluruhan. Penerbitan akses terbuka, menjadi tren baru dalam penelitian ilmu sosial di India selama beberapa tahun terakhir, yang meningkatkan visibilitas hasil penelitian oleh para sarjana India Pola kepengarangan dan pengukuran menunjukkan tren menuju model bersama atau kolaboratif yang jelas menunjukkan adanya penelitian yang bekerja kelompok dan publikasi telah memperhatikan di tingkat internasional melalui sejumlah besar kontribusi peneliti asing. Studi ini menemukan bahwa dari 1.195 artikel, 717 artikel (60\%) telah dikutip di waktu yang berbeda dengan jumlah 6078 kutipan yang merupakan bukti tren kualitas publikasi.

Barik dan Jena (2019) melakukan analisis bibliometrik dari 10 jurnal akses terbuka di bidang Ilmu Perpustakaan dan Informasi (LIS). Studi ini bermaksud untuk membangun gagasan tentang pertumbuhan publikasi tahunan, negara-negara yang paling berkontribusi, lembaga yang paling berkontribusi, jenis dokumen yang diterbitkan, publikasi yang paling banyak dikutip, penulis yang produktif, dampak kutipan, pola kepenulisan, dan beberapa aspek bibliometrik lainnya dari jurnal-jurnal ini. Temuan dalam studi mengungkapkan bahwa ada pertumbuhan yang stabil dari literatur yang terlihat di jurnal akses terbuka LIS selama periode penelitian. Sekitar 83 negara dan 990 institut / universitas di seluruh dunia telah berkontribusi pada jurnal-jurnal ini. Amerika Serikat adalah negara pemimpin di antara semuanya negara yang berkontribusi. Publikasi dalam jurnal akses terbuka LIS didominasi oleh pola kepenulisan tunggal. Juga, beberapa aspek lain dari jurnal-jurnal ini yang telah diungkapkan dalam penelitian ini akan sangat bermanfaat bagi para profesional perpustakaan, peneliti LIS dan anggota fakultas untuk pemilihan jurnal akses terbuka LIS.

Raimbault, $d k k$ (2019) mengatakan bahwa bibliometrik banyak digunakan oleh penulis dan jurnal untuk memantau, mengevaluasi dan mengidentifikasi pembaca mereka di dunia ilmiah yang semakin berkembang. Kontribusi dapat memperkenalkan alat analisis corpus multi-metode yang khusus dirancang untuk corpus ilmiah dengan konten spasial. Penelitian ini mengusulkan aplikasi interaktif khusus yang mengintegrasikan tiga strategi untuk membangun jaringan semantik, menggunakan kata kunci, kutipan (bidang penelitian menggunakan makalah) dan teks lengkap (tema berasal dari kata-kata yang digunakan dalam penulisan). Jaringan dapat dipelajari 
sehubungan dengan evolusi temporal mereka serta ekspresi spasial mereka, dengan mempertimbangkan negara-negara yang diteliti dalam makalah yang dianalisis. Hal yang sama dilakukan oleh Devos (2011) yang menggunkan bibliometrik untuk mengevaluasi hasil penelitian yang telah dilakukan. Bibliometrik dilakukan dalam periode waktu tertentu misalnya 3-5 tahun dan umumnya menggunakan dua pendekatan, yaitu jumlah publikasi, indikator yang mengukur produktivitas, dan jumlah kutipan, indikator yang mengukur dampak dari artikel yang dihasilkan. Saat ini, analisis bibliometrik digunakan untuk seleksi jumal untuk perpustakaan, dan forecasting terhadap riset-riset yang potensial dalam suatu bidang ilrnu, dan evaluasi keluaran ilrnu pengetahuan (Baby dan Kurnaravel, 2011).

Sains terbuka mendorong pengetahuan yang transparan, dapat diakses secara bebas, tersebar luas, dan dapat dikembangkan bersama melalui jaringan kolaboratif. Keterbukaan ilmu pengetahuan utamanya ditekankan pada hasil penelitian yang didanai oleh publik atau pajak rakyat. Telah lama ada anggapan bahwa ilmuwan hidup di menara gading, terisolasi dari realitas di sekitarnya. Tidak mudah bagi masyarakat umum untuk mengakses secara luas hasil karya dan pemikiran para ilmuwan, akibat dominasi penerbit komersial yang mengkapitalisasi ilmu pengetahuan. Kondisi kesenjangan ini melahirkan gagasan bahwa ilmu pengetahuan tidak seharusnya dikomersialkan, sehingga melahirkan gerakan Sains Terbuka .

Menurut Miedema, Mayer, Holmberg, Leonelli.; ( 2018) konsep keterbukaan dalam Sains terbuka mancakup akses terbuka, sumber terbuka, metodologi terbuka, tinjauan mitra bestari terbuka, dan pendidikan terbuka. Berdasarkan permasalahan tersebut di atas, dirumuskan permasalahan sebagai berikut; (1)Bagaimana perkembangan produktivitas publikasi ilmiah tentang sains terbuka berdasarkan tahun? (2)Bagaiman perkembangan jurnal inti yang mempublikasikan tentang sains terbuka ? (3)Bagaimana perkembangan jumlah penulis tentang sains terbuka yang terproduktif? (4)Bagaiamana perkembangan lembaga/afiliasi yang berperan dalam publikasi ilmiah tentang sains terbuka? (5)Bagaiman perkembangan publikasi ilmiah tentang sains terbuka berdasarakan negara? (6)Bagaimana perkembangan publikasi ilmiah sains terbuka berdasarkan tipe dokumen? (7)Bagaimana perkembangan publikasi ilmiah tentang sains terbuka berdasarkan sponsor pendanaan? (8)Bagaimana peta perkembangan publikasi ilmiah tentang sains terbuka berdasarkan clustering kata kunci?

Berdasarkan latar belakang dan permasalah tersebut di atas, dilakukan kajian pemetaan bibliometrik perkembangan penelitian sains terbuka periode 2000-2019 bebasis data scopus.

\section{METODE PENELITIAN}

Kajian ini dilakukan dengan cara melakukan penelusuran melalui database Scopus (http://www.scopus.com). Penelusuran pada database Scopus menggunakan istilah atau kata kunci "open science" dengan hasil penelusuran yang diambil yang terdapat pada judul. Data yang digunakan dalam penelitian ini adalah data hasil penelitian/ karya ilmiah yang didapatkan dari database Scopus. Data yang diambil adalah data publikasi bidang ilmu sains terbuka dalam kurun waktu 20 tahun terakhir (2000-2019). Tahapannya adalah mengumpulkan data berdasarkan tahun mulai 2000 sampai dengan 2019. Melakukan eksplorasi data pada data base Scopus untuk melihat pertumbuhan publikasi ilmiah literatur tentang sains terbuka; jurnal inti; produktivitas dan kolaborasi peneliti; pertumbuhan publikasi berdasarkan lembaga/ afiliasi dan jumlah publikasi berdasarkan negara. Sedangkan untuk memvisualisasikan perkembangan penelitian tentang sains terbuka digunakan software VOSviewer. Cara pembuatan peta adalah dengan cara meng- export hasil penelusuran dari database scopus ke format CSV, kemudian di-input ke dalam software VOSviewer. 


\section{HASIL DAN PEMBAHASAN}

\section{Hasil Produktivitas Publikasi Ilmiah Tentang Sains Terbuka Berdasarkan Tahun}

Dari hasil penelusuran melalui database Scopus menunjukkan bahwa produktivitas publikasi ilmiah mulai tahun 2000-2019 mengalami peningkatan yang signifikan. Peningkatan terjadi secara signifikan mulai terjadi dari dari tahun 2014 sampai tahun 2019. Produktivitas tertinggi terjadi pada tahun 2018 yaitu sebanyak 230 publikasi, kemudian disusul tahun 2019 sebanyak 2013 publikasi, tahun 2017 sebanyak 172 publikasi, tahun 2015 sebanyak 122 publikasi, tahun 2016 sebanyak 117 publikasi dan tahun 2014 sebanyak 111 publikasi. Penelitian bibliometrik sejenis pernah dilakukan oleh Strork dan Astrin (2014) yang mengkaji tren penelitian biodiversitas menggunakan menggunakan pangkalan data Web of science. Hasil penelitian menunjukkan bahwa kontribusi artikel, jumlah pengaran dan jurnal meningkat sekitar tahun 1980an yaitu ketika istilah biodiversitas diciptakan. Selengkapanya produktivitas publikasi ilmiah tentang sains terbuka dapat dilihat pada Tabel 1.

Tabel 1

\begin{tabular}{cc} 
Produktivitas publikasi ilmiah tentang sains terbuka berdasrakan Tahun \\
\cline { 1 - 2 } Tahun & Jumlah publikasi \\
\hline 2019 & 203 \\
2018 & 230 \\
2017 & 172 \\
2016 & 117 \\
2015 & 122 \\
2014 & 111 \\
2013 & 69 \\
2012 & 95 \\
2011 & 76 \\
2010 & 51 \\
2009 & 51 \\
2008 & 43 \\
2007 & 40 \\
2006 & 34 \\
2005 & 22 \\
2004 & 18 \\
2003 & 11 \\
2002 & 11 \\
2001 & 5 \\
2000 & 10 \\
Jumlah & 1,491 \\
\hline
\end{tabular}

\section{Jurnal Inti Publikasi Ilmiah Tentang Sains Terbuka Terbanyak}

Jurnal inti terbanyak yang mempublikasikan publikasi ilmiah sains terbuka adalah Royal Society Open Science sebanyak 26 publikasi, kemuadian dsusul Journal of Physics Conference Series 23 publikasi, Nature 18 publikasi. Selengkapnya sepuluh jurnal inti terbanyak yang mempublikasikan tentang open science dapat dilihat pada Tabel 2. 
Tabel 2

Jurnal inti terbanyak yang mempublikasikan tentang sains terbuka

\begin{tabular}{lc}
\hline Jurnal Inti & Jumlah publikasi \\
\hline Royal Society Open Science & 26 \\
Journal Of Physics Conference Series & 23 \\
Nature & 18 \\
ACM International Conference Proceeding Series & 16 \\
Ceur Workshop Proceedings & 16 \\
Lecture Notes In Computer Science Including & 15 \\
Subseries Lecture Notes In Artificial Intelligence & \\
And Lecture Notes In Bioinformatics & \\
Communications In Computer And Information & 13 \\
Science & \\
Science & 13 \\
Information Wissenschaft Und Praxis & 11 \\
Plos Biology & 10 \\
\hline
\end{tabular}

\section{Jumlah Penulis Tentang Sains Terbuka Terbanyak}

Dari hasil penelusuran melalui database Scopus selama periode tahun 2000-2019 menunjukkan bahwa penulis yang paling produktif menulis tentang sains terbuka adalah Quick, $R$ sebanyak 9 publikasi, kemudian disusul Ross, J.S sebanyak 8 publikasi, Bockelman, B dan pordes, R masing masing sebanyak 7 publikasi. Adapun David, P.A, Gardner, R, Joly, R, Manghi, P, Roy, A, dan Schroeder, R masing-masing 6 publikasi. Selengkapanya sepuluh penulis terbanyak yang mempublikasikan tentang sains terbuka dapat dilihat pada Tabel 3.

Tabel 3

Sepuluh penulis terbanyak tentang sains terbuka

\begin{tabular}{lc}
\hline Penulis & Jumlah publikasi \\
\hline Quick, R. & 9 \\
Ross, J.S. & 8 \\
Bockelman, B. & 7 \\
Pordes, R. & 7 \\
David, P.A. & 6 \\
Gardner, R. & 6 \\
Joly, Y. & 6 \\
Manghi, P. & 6 \\
Roy, A. & 6 \\
Schroeder, R. & 6 \\
\hline
\end{tabular}

\section{Jumlah Publikasi Tentang Sains Terbuka Berdasarkan Afiliasi/ Lembaga}

Sepuluh afiliasi terbanyak yang mempublikasikan tentang sains terbuka adalah University of Toronto sebanyak 23 publikasi, kemudian disusul Indiana University dan The University of Chicago masing masing 22 publikasi, McGill University 21 publikasi, University of Wisconsin-Madison 20 publikasi, Stanford University dan University of Oxford masing masing 19 publikasi. Selengkapnya afiliasi/lembaga terbanyak yang mempublikasikan tentang sains terbuka dapat dilihat pada Tabel 4. 
Sepuluh Afiliasi /Lembga dengan publikasi sains terbuka terbanyak

\begin{tabular}{lc}
\hline \multicolumn{1}{c}{ Afiliasi/Lembaga } & Jumlah publikasi \\
\hline University of Toronto & 23 \\
Indiana University & 22 \\
The University of Chicago & 22 \\
McGill University & 21 \\
University of Wisconsin-Madison & 20 \\
Stanford University & 19 \\
University of Oxford & 19 \\
UCL & 18 \\
Consiglio Nazionale delle Ricerche & 17 \\
Argonne National Laboratory & 16 \\
\hline
\end{tabular}

\section{Jumlah Publikasi Berdasarkan Negara}

Bedasarkan negara menunjukkan bahwa negara yang terproduktif mempublikasikan tentang sains terbuka adalah Amerika serikat dengan jumlah publikasi terbanyak 476 dokumen, kemudian disususl Inggris sebanyak 199 dokumen, Germany 122 dokumen, Italy 77 dokumen. Adapun yang paling sedikit dari sepuluh negara terbanyak yang mempublikasikan sains terbuka adalah Netherland yaitu sebanyak 44 dokumen. Selengkapnya publikasi tentang sains terbuka yang dihasilkan oleh sepuluh negara terbanyak dapat dilihat pada Tabel 5.

Tabel 5

Jumlah publikasi sains terbuka berdasarkan negara

\begin{tabular}{lc}
\hline \multicolumn{1}{c}{ Negara } & Jumlah Dokumen \\
\hline United States & 476 \\
United Kingdom & 199 \\
Germany & 123 \\
Italy & 77 \\
Canada & 75 \\
France & 57 \\
Spain & 57 \\
India & 54 \\
Japan & 51 \\
Netherlands & 44 \\
\hline
\end{tabular}

\section{Jumlah Publikasi Berdasarkan Tipe Dokumen}

Dari hasil penelusuran melalui database scopus menunjukkan bahwa tipe dokumen publikasi sains terbuka yang terbanyak adalah dalam bentuk artikel yaitu sebanyak 628 dokumen, kemudian disusul conference paper sebanyak 339 dokumen, editorial sebanyak 144, review sebanyak 95 dokumen. Adapun publikasi sains terbuka yang paling sedikit adalah data paper hanya 1 dokumen. Selengkapnya rincian publikasi ilmiah tentang sains terbuka dapat dilihat pada Tabel 6. 


\begin{tabular}{lc}
\hline Tipe Dokumen & Jumlah dokumen \\
\hline Article & 628 \\
Conference Paper & 339 \\
Editorial & 144 \\
Review & 95 \\
Erratum & 79 \\
Note & 76 \\
Book Chapter & 62 \\
Letter & 30 \\
Short Survey & 21 \\
Book & 8 \\
Conference Review & 6 \\
Data Paper & 1 \\
\hline
\end{tabular}

\section{Jumlah Publikasi Tentang Sains Terbuka Berdasarkan Sponsor Pendanaan}

Berdasarkan Tabel 7 menunjukkan bahwa hasil penelitian tentang publikasi sains terbuka yang terbanyak mendapatkan sponsor penandanaan dari National Science Foundation sebesar 54 publikasi, kemudian disusul National Institutes of Health sebanyak 31 publikasi, European Commission 19 publikasi, National Natural Science Foundation of China dan Wellcome Trust masing-masing sebesar 14 publikasi, Economic and Social Research Council dan Engineering and Physical Sciences Research Council masing- masing 11 publikasi. Adapun .yang paling sedikit adalah sponsor penandanan dari Canadian Institutes of Health Research dan Genome Canada masing masing 8 publikasi. Sellengkapanya rincian jumlah publikasi sains terbuka yang mendapatkan sponsor penandanaan.

Tabel 7

Jumlah publikasi tentang sains terbuka berdasarkan sponsor penandanaan

\begin{tabular}{lc}
\hline Funding sponsor & Jumlah dokumen \\
\hline National Science Foundation & 54 \\
National Institutes of Health & 31 \\
European Commission & 19 \\
National Natural Science Foundation of China & 14 \\
Wellcome Trust & 14 \\
Economic and Social Research Council & 11 \\
Engineering and Physical Sciences Research Council & 11 \\
Bill and Melinda Gates Foundation & 9 \\
Canadian Institutes of Health Research & 8 \\
Genome Canada & 8 \\
\hline
\end{tabular}

\section{Peta Perkembangan Tentang Sains Terbuka}

Dari Gambar 1 menunjukkan bahwa peta perkembnagan penelitian sains terbuka dari tahun 2000-2019 terbagi menjadi 8 kluster dengan rincian sebagai berikut. Kluster 1 adalah warna merah merupakan kluster yang paling banyak diteliti yang terdiri dari 146 topik dengan rincian topik teratas adalah big data, zitizen science, cloud computing, collabotarive research, computer science, data analytics, data science, digital libraries, digital storage, e-science, metadata, open data, open innovation, open science, dan scientific data. Kluster 2 berwarna hijau dengan jumlah topik sebanyak 60 yang terbanyak adalah bibliometrics, decision making, funding, genetic database, patent, research support as topik, science and scientis. Kluster 3 berwarna biru yang terdiri dari 48 topik dengan rincian jumlah terbanyak adalah biomedical research, clinical research, drug industry, drug research, drug safety, evaluation research, heath science, medical information, 
qualitative research, questionare, dan review. Kluster 4 berwarna kuning yang terdiri dari 45 topik dengan jumlah terbanyak algorithm, biochemistry, bioinformatics, biological science diciplines, biology, biomedicine, copmuter program, database, data sharing, publication dan reseach design. Kluster 5 berwarna merah muda yang terdiri dari 42 topik dengan jumlah terbanyak adalah topik acces to information, ecosystem, information disemination, inforamtion srvice, inforamtion system, internet, journal impac factor, online system, open access publishing, dan peer review. Kluster 6 berwana biru muda terdiri dari 31 topik dengan jumlah terbanyak adalah topik artificial intelegency, business model, citation analysis, computer networks, ebook, electronic publishing, information science, library and information science, open access, research activiti, social science dan technology.

Hal tersebut sesuai dengan pendapat Royani $d k k$ (2013) bahwa peta pengetahuan dapat memperlihatkan pertumbuhan suatu bidang ilmu tertentu.

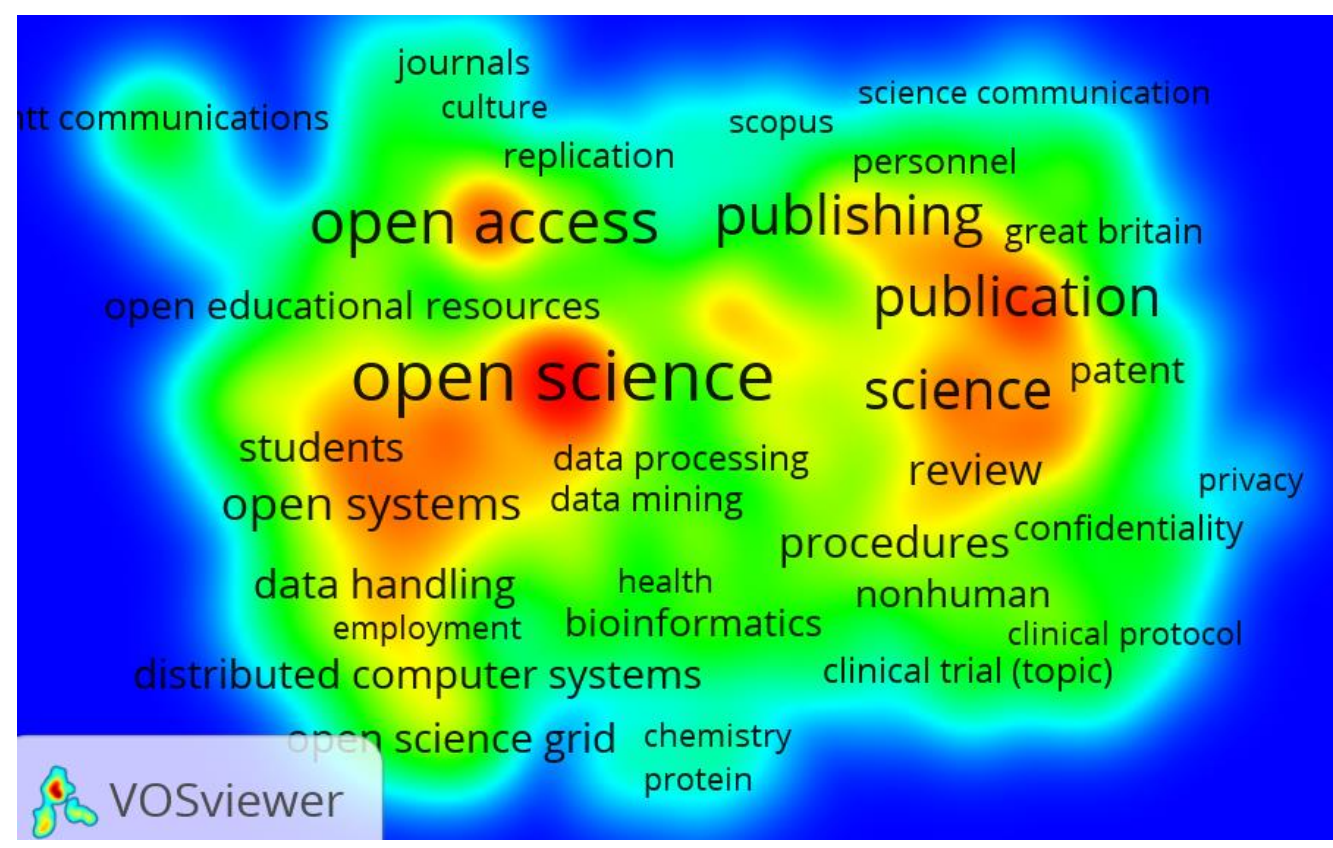

Gambar 1

Peta perkembangan publikasi tentang sains terbuka

\section{Pembahasan}

Hasil kajian bibliometrik tentang sains terbuka yang terindeks di database Scopus dari 2000 sampai dengan tahun 2019 menunjukkan bahwa ada sebanyak 1491 publikasi. Pertumbuhan publikasi penelitian tentang sains terbuka yang terindeks di Scopus puncaknya terjadi pada tahun 2018 yaitu sebanyak 230 publikasi. Jurnal inti terbanyak yang mempublikasikan publikasi ilmiah open science adalah Royal Society Open Science sebanyak 26 publikasi, kemuadian dsusul Journal Of Physics Conference Series 23 publikasi, Nature 18 publikasi. Hal tersebut senanda penelitian Kumar (2016) yang melakukan analisis bibliometrik jurnal akses terbuka dengan subjek 'matematika' yang diindeks dalam directory of open access journals (DOAJ). Hasil kajian menunjukkan bahwa jurnal terbanyak dalam subjek matematika diindeks di DOAJ adalah bidang sains.

Penulis yang paling produktif menulis tentang sains terbuka adalah Quick, $\mathrm{R}$ dari Indiana University, Bloomington, United States sebanyak 9 publikasi, kemudian disusul Ross, J.S sebanyak 8 publikasi, Bockelman, $B$ dan Pordes, $R$ masing masing sebanyak 7 publikasi. Adapun berdasrkan afiliasi terbanyak yang mempublikasikan tentang sains terbuka adalah University of Toronto sebanyak 23 publikasi, kemudian disusul Indiana University dan The University of Chicago 
masing masing 22 publikasi. Dilihat bedasarkan negara menunjukkan bahwa negara yang terproduktif mempublikasikan tentang sains terbuka adalah Amerika serikat dengan jumlah publikasi terbanyak 476 dokumen, kemudian disususl Inggris sebanyak 199 dokumen, Germany 122 dokumen, dan Italy 77 dokumen. Hasl tersebut sesuai dengan hasil penelitian Kirtania (2018) yang melaporkan bahwa negara-negara paling produktif berkontribusi dalam bidang akses terbuka literatur ilmu sosial adalah Inggris kemudian diikuti oleh Amerika Serikat, Spanyol dan Cina. Hal senada juga didukung hasil penelitian dari Barik (2019) yang melakuan anlisis bibliometrik terhadap 10 jurnal akses terbuka di bidang Ilmu Perpustakaan dan Informasi (LIS). Hasil penelitian menunjukkan bahawa sekitar 83 negara dan 990 institut / universitas di seluruh dunia telah berkontribusi pada jurnal-jurnal akses terbuka ini. Amerika Serikat merupakan negara paling banyak berkontribusi dalam penerbitan jurnal akses terbuka bidang perpustakaan dan informasi di antara semuanya negara yang berkontribusi.

Dari hasil penelusuran melalui database Scopus menunjukkan bahwa tipe dokumen publikasi sains terbuka yang terbanyak adalah dalam bentuk artikel yaitu sebanyak 628 dokumen, kemudian disusul conference paper sebanyak 339 dokumen, editorial sebanyak 144, review sebanyak 95 dokumen. Hal tersebut dikdukung oleh Kirtania (2018) menunjukkan bahwa berdasrakan tipe dokumen publikasi terbanyak diterbitkan dalam artikel jurnal $(77,49 \%)$ dan diikuti oleh makalah konferensi $(13,64 \%)$.

Publikasi sains terbuka yang terbanyak mendapatkan sponsor penandanaan dari National Science Foundation sebesar 54 publikasi, kemudian disusul National Institutes of Health sebanyak 31 publikasi, European Commission 19 publikasi, National Natural Science Foundation of China dan Wellcome Trust masing-masing sebesar 14 publikasi, Economic and Social Research Council dan Engineering and Physical Sciences Research Council masing- masing 11 publikasi.

Berdasrkan hasil pemetaan menggunakan sofware VOSviewer menunjukkan bahwa dalam peta perkembangan publikasi sains terbuka terbagi menjadi 6 kluster. Dari masing masing kluster terdiri dari beberapa topik. Kluster yang terbanyak anggotanya adalah kluster 1 yang berwana merah dengan jumlah topik sebanyak 146 dengan rincian topik teratas adalah big data, zitizen science, cloud computing, collabotarive research, computer science, data analytics, data science, digital libraries, digital storage, e-science, metadata, open data, open innovation, open science, dan scientific data.

\section{SIMPULAN}

Beradsarkan hasil dan pembahasan dapat diambil kesimpulan bahwa pertumbuhan publikasi ilmiah tentang sains terbuka yang terindeks di Scopus puncaknya terjadi pada tahun 2018 yaitu sebanyak 230 publikasi. Jurnal inti terbanyak yang mempublikasikan publikasi ilmiah sains terbuka adalah Royal Society Open Science sebanyak 26 publikasi. Penulis yang paling produktif menulis tentang sains terbuka adalah Quick, $R$ dari Indiana University. Dilihat bedasarkan negara menunjukkan bahwa negara yang terproduktif mempublikasikan tentang sains terbuka adalah Amerika serikat dengan jumlah publikasi terbanyak 476 dokumen. Dokumen publikasi ilmiah tentang sains terbuka yang terbanyak adalah dalam bentuk artikel yaitu sebanyak 628 dokumen serta mendapat sponsor penandanaan dari National Science Foundation sebesar 54 publikasi. Menggunakan sofware VOSviewer menunjukkan bahwa peta perkembangan publikasi ilmiah tentang sains terbuka terbagi menjadi 6 kluster. 


\section{DAFTAR PUSTAKA}

Anil, S., Kademani, B. S., Garg, R. G., \& Kumar, V. (2010). Scientometric mapping of Tsunami publications: a citation based study. Malaysian Journal of Library \& Information Science, 15(1), 23-40.

Baby, K. and Kumaravel, J.P.S. (2011). Indian Journal of experimental biology: A bibliometric analysis. SALIS Journal ofInformation Management and Tecnology, 2(1), 1-9

Barik, N., Jena, P. (2019). Bibliometric portrait of select Open Access Journals in the field of Library and Information Science: A Scopus based analysis" (2019). Library Philosophy and Practice (e-journal). 2588. https://digitalcommons.unl.edu/libphilprac/2588. Akses 31 Desember 2019

Devos, Patrick. (2011). Research and Bibliometrics: A Long History. Clinics and Research in Hepatology and Gastroenterology, 35( 5), 336-337.

Foster. (2018) Open science. Diakses dari https://www.fosteropenscience.eu/fostertaxonomy/open-science diakses 27 Desember 2019.

Irawan, D. E. , Rachmi, C. N., Irawan, H., Abraham,J., Kusno, K., Multazam, M. T., Rosada, K. K, Nugroho, S. H., Kusumah, G., Holidin, D., Aziz, N. A. (2017). Penerapan Open Science di Indonesia agar riset lebih terbuka, mudah diakses, dan meningkatkan dampak saintifik. Berkala Ilmu Perpustakaan dan Informasi, 13 (1),

Kirtania, D. K. (2018). Bibliometric Study of Indian Open Access Social Science Literature" Library Philosophy and Practice (e-journal). 1867. Diakses dari http://digitalcommons.unl.edu/libphilprac/1867, Tanggal 30 Desember 2019.

Kumar, J. (2016). Bibliometric Analysis of Open Access Journals in Mathematics Indexed in DOAJ Database. Journal of Advancements in Library Sciences 3(2 ), 50-88

Miedema, F., Mayer, K., Holmberg, K., \& Leonelli, S. (2018). Mutual Learning Exercise. Open Science: Altmetrics and Rewards. European Commission. Directorate-General for Research and Innovation

OECD. (2007). Principles and guidelines for access to research data from public funding. Diakses dari http://www.oecd.org/dataoecd/9/61/38500813.pdf. tanggal 27 Desember 2019.

Raimbault, J., Chasset, P.-O., Cottineau, C., Commenges, H., Pumain, D., Kosmopoulos, C., \& Banos, A. (2019). Empowering open science with reflexive and spatialised indicators. Environment and Planning B: Urban Analytics and City Science, 239980831987081. doi:10.1177/2399808319870816. Diakses Tanggal 31 Desember 2019

Royani, Y., Bachtar, M. A., Tambunan, K., Tupan, T., \& Alm, S (2013). Pemetaan Karya Tulis Ilmiah LPNK: Studi Kasus LIPI dan BPPT (2004-2008). Baca: Jurnal Dokumentasi Dan Informasi , 34 (1).

Setyowati, Lis and Heriyanto (2019). Research Data Management In Higher Educations: Knowledge Mapping Using Bibliometric Analysis. 2nd International Conference on Documentation and Information LIPI Jakarta, August 6-7th, 2019 
Stork, H., \& Jonas J. Astrin . (2014). Trends in Biodiversity Research-A Bibliometric Assessment. Open Journal of Ecology, 4, 354-370.

Vicente-Sáez, R., \& Martínez-Fuentes, C. (2018). Open Science now: A systematic literature review for an integrated definition. Journal of business research, 88, 428-436. 